\title{
Human Choriogonadotropin-like Material in Bacteria of Different Species: Electron Microscopy and Immunocytochemical Studies with Monoclonal and Polyclonal Antibodies
}

\author{
By HERNAN F. ACEVEDO, ${ }^{1 *}$ MATIAS PARDO, ${ }^{1}$ \\ ELIZABETH CAMPBELL-ACEVEDO ${ }^{1}$ AND GERALD J. DOMINGUE \\ ${ }^{1}$ Department of Laboratory Medicine, Allegheny-Singer Research Institute, Allegheny General \\ Hospital, Pittsburgh, PA 15212, USA \\ ${ }^{2}$ Department of Urology and Microbiology-Immunology, Tulane University School of Medicine, \\ New Orleans, LA 70112, USA
}

(Received 27 August 1986; revised 31 October 1986)

\begin{abstract}
Immunocytochemical studies using antisera to whole human choriogonadotropin (hCG), to its $\alpha$ - and $\beta$-subunits and to the $\mathrm{COOH}$-terminal peptide of hCG $\beta$, and two monoclonal antibodies to $\mathrm{hCG} \beta$, demonstrated expression of hCG-like material, its individual subunits and/or fragments in nine bacterial strains. Seven of these were isolated from patients with cancer and were definitely identified as Streptococcus faecalis (three strains), Staphylococcus haemolyticus (two strains) and Staphylococcus epidermidis and Escherichia coli (single strains). The other two strains were cell-wall-deficient (CWD) variants, one identified as Streptococcus bovis, isolated from the blood of a patient with a fever of unknown origin and a possible brain abscess. The other was a Gram-negative diphtheroid isolated from the urine of a pregnant woman, which during the period of study reverted to a Gram-positive Corynebacterium identified as a ' $C$. ulcerans' strain and expressed the hCG-like factor only during its phase as Gram-negative diphtheroid. Electron microscopy of these nine strains (including negative controls of strains of the same species subjected to the same immunocytochemical analyses and under identical cultural conditions) revealed morphological alterations in the bacterial cell walls and cytoplasmic material and/or bizarre forms of reproduction in six of the nine strains expressing hCG-like material including the two CWD variants. Collectively, these results provided evidence that (1) hCG-producing bacteria isolated from patients with overt cancer are not a new and unique species as claimed by others, and (2) there is a close resemblance between the bacterial protein and the human trophoblastic hormone, based on immunochemical recognition of different parts of the hCG molecule. The morphological changes observed by electron microscopy may indicate that some of the bacteria expressing hCG-like material are revertants of CWD variants.
\end{abstract}

\section{INTRODUCTION}

Several strains of bacteria capable of synthesizing and expressing in their cell membrane a material with immunological, physicochemical and in vitro and in vivo biological properties similar to those of human choriogonadotropin (hCG), the human trophoblastic hormone, have been isolated from tissues and urine. Most of those isolates were from cancer patients (Livingston \& Alexander-Jackson, 1970; Cohen \& Strampp, 1976; Acevedo et al., 1978, 1979, 1981 a, 1985; Maruo et al., 1979; Backus \& Affronti 1981; Domingue et al., 1986). These findings have important biological implications (Domingue et al., 1986) because (1) they constituted the first demonstration of the natural synthesis by prokaryotes of a biologically active material

\footnotetext{
Abbreviations: hCG, human choriogonadotropin; CWD, cell wall deficient; MoAb, monoclonal antibody; TEM, transmission electron microscopy.
} 
similar to the human dimeric sialoglycoprotein hormone, (2) most of the isolates were from patients with clinically manifested cancer, and (3) the expression of the hCG-like material resided in bacterial species belonging to the indigenous flora of man (Acevedo et al., 1978, 1980, $1981 a, 1985$; Backus \& Affronti, 1981). Consequently we started a systematic investigation for the presence of the hCG-like material in bacteria with the aim of determining: $(a)$ the extent to which bacteria express the hCG-like material; $(b)$ if the expression of the hCG-like material is a strain or a species characteristic; $(c)$ if all strains of different species isolated from cancer patients express the hCG-like material; $(d)$ whether the presence of hCG-like material is limited to bacteria isolated from humans and animals with clinically manifested cancer; and $(e)$ if morphological and/or ultrastructural differences exist between the bacteria capable of expressing the hCG-like material and those that do not. As part of this effort; we report the results (i) of detailed identification; (ii) of immunocytochemical analysis using a battery of polyclonal and monoclonal antibodies, and (iii) of transmission electron microscopy (TEM) studies done in nine strains of bacteria expressing the hCG-like material, hereafter called hCGproducers, and their corresponding nonproducing control bacteria, mainly in order to establish if morphological differences at the ultrastructural level exist between the hCG-producers and the nonproducers, and to establish if the bacteria expressing hCG-like material are a unique species as has been postulated by Livingston \& Livingston (1974).

\section{METHODS}

Bacterial cultures. Five of the nine strains, coded as PC followed by letters or numbers, were originally isolated from tissue and/or urine of five cancer patients of Dr Livingston-Wheeler (The Livingston Clinic, San Diego, Calif., USA) and identified by her as 'Progenitor cryptocides' (Livingston \& Livingston, 1974). Four strains were received directly from the Livingston Clinic, the fifth, PC-RU1, was given to us by Dr S. S. Koide (Rockefeller University Biomedical Division, The Population Council, New York, NY, USA) and was identified at that time as being an atypical Staphylococcus simulans (Acevedo et al., 1981a). Origins and identification of Escherichia coli strain M3 and Streptococcus faecalis (Lancefield group D) strain AK have been reported (Acevedo et al., 1978, 1981 a). Strain AV-46 was isolated in New Orleans from blood of a patient with a fever of unknown origin and with a possible brain abscess, by methods previously reported (Domingue \& Schlegel, 1977); it was a cell-wall-deficient (CWD) variant by isolation, cultural and morphological characteristics (Domingue, 1982; Heidger et al., 1982). Strain JB-I was isolated from the urine of a young pregnant woman. Because of its morphology and biochemical characteristics demonstrated during the period of study, this bacterium was also considered a revertant of a CWD form.

Identification methods. Identification was done by standard morphological, nutritional and biochemical tests. The coagulase-negative Straphylococcus species were identified according to methods described in the conventional Kloos \& Schleifer (1975) scheme and with the API STAPH-IDENT Staphylococcal System (Analytab Products) (Kloos \& Wolfshohl, 1982). Identification of two Staphylococcus strains was further verified on the basis of their DNA relatedness to species reference or type strains using DNA-DNA hybridization techniques (Brenner et al., 1969; Kloos \& Wolfshohl, 1979). Complete identification of the micro-organisms permitted the use of well-characterized non-producing strains of the species under study as controls for the immunocytochemical and electron microscopy studies.

Immunocytochemical methods. Detection of the hCG-like immunoreactive material in the nine strains was done at the light microscope level by utilizing the indirect fluorescein-labelled and the indirect peroxidase-labelled reactions by procedures previously described (Acevedo $e t$ al., 1980). The non-producing control bacteria were tested in the same manner. For immunocytochemistry all bacteria were grown at $35^{\circ} \mathrm{C}$ in Trypticase soy broth and $/$ or on $5 \%(\mathrm{v} / \mathrm{v})$ sheep blood in Columbia agar base (BBL). For examination, a drop of sterile water was placed in each of the circles of a Fluoroslide (Curtin Matheson), and then the surface of one or several colonies of the respective micro-organisms was gently touched with a bacteriological loop and mixed into the drop of water in each circle. After air drying the preparations were immediately processed.

Immunological reagents. Rabbit antiserum to whole hCG was obtained from Cappel Laboratories (now Cooper Biomedical, Inc., Malvern, Pa., USA) and from Miles-Yeda. Rabbit antiserum to the $\beta$-subunit of hCG (HCG $\beta$ ) was given to us by V. C. Stevens (H-9; The Ohio State University College of Medicine Columbus, Ohio, USA) and by S. Birken (R-126 and R-127; Department of Medicine, College of Physicians and Surgeons, Columbia University, New York, NY, USA), who also supplied antisera to the $\alpha$-subunit of hCG (R-111 and R-112) as well as to the carboxy-terminal peptide of hCG $\beta$, residues 115-145 (R-525) (Birken \& Canfield, 1980; Birken et al., 1982). Hao-Chia Chen (National Institute of Child Health and Human Development, NIH, Bethesda, Md., USA) provided us with another antiserum (MU-9) to the carboxy-terminal peptide of hCG $\beta$ (residues 111-145). 
Table 1. Immunocytochemical detection of hCG-like material in bacteria of different species

\begin{tabular}{|c|c|c|c|c|c|c|c|c|}
\hline \multirow[b]{2}{*}{ Species } & \multirow[b]{2}{*}{ Strain* } & \multicolumn{6}{|c|}{ Reaction to antiserum or antibody $\dagger$ : } & \multirow[b]{2}{*}{ Source } \\
\hline & & Whole & $\begin{array}{c}\text { MoAb } \\
\text { 3F8 }\end{array}$ & $\begin{array}{l}\text { MoAb } \\
337 \mathrm{~W}\end{array}$ & $\beta$ & $\beta \mathrm{COOH}$ & $\alpha$ & \\
\hline Staph. haemolyticus & 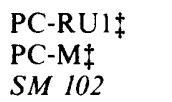 & $\begin{array}{l}+ \\
+ \\
-\end{array}$ & $\begin{array}{l}+ \\
+ \\
-\end{array}$ & $\begin{array}{l}+ \\
+ \\
-\end{array}$ & $\begin{array}{l}+ \\
+ \\
-\end{array}$ & $\begin{array}{l}+ \\
+ \\
-\end{array}$ & $\begin{array}{l}+ \\
+ \\
-\end{array}$ & $\begin{array}{l}\text { Metastatic } \\
\text { cancer patients } \\
\text { Lab. isolate, normal }\end{array}$ \\
\hline Staph. epidermidis & $\begin{array}{l}\text { PC-A } \\
\text { Wild }\end{array}$ & $\begin{array}{l}+ \\
-\end{array}$ & $\begin{array}{c}- \\
\text { ND }\end{array}$ & $\begin{array}{l}\text { VE } \\
\text { ND }\end{array}$ & $\begin{array}{l}+ \\
-\end{array}$ & $\begin{array}{l}+ \\
-\end{array}$ & $\overline{\mathrm{ND}}$ & $\begin{array}{l}\text { Breast cancer patient } \\
\text { Lab. isolate, normal }\end{array}$ \\
\hline Strep. faecalis & $\begin{array}{l}\text { PC-C } \\
\text { PC-E } \\
\text { AK } \\
\text { Wild }\end{array}$ & $\begin{array}{l}+ \\
\text { ND } \\
+ \\
-\end{array}$ & $\begin{array}{c}- \\
+ \\
\text { VE } \\
-\end{array}$ & $\begin{array}{l}+ \\
- \\
+ \\
\text { ND }\end{array}$ & $\begin{array}{l}+ \\
+ \\
-\end{array}$ & $\begin{array}{l}+ \\
+ \\
-\end{array}$ & $\begin{array}{l}- \\
+ \\
-\end{array}$ & $\begin{array}{l}\text { Multiple myeloma } \\
\text { patient } \\
\text { Lung cancer patient } \\
\text { Cancer (nasopharynx) } \\
\text { Lab. isolate, normal }\end{array}$ \\
\hline Strep. bovis & $\begin{array}{l}\text { AV }-46 \\
Z A K\end{array}$ & + & $\begin{array}{l}\text { VE } \\
-\end{array}$ & $\begin{array}{l}\text { VE } \\
-\end{array}$ & $\begin{array}{l}+ \\
-\end{array}$ & $\begin{array}{l}+ \\
-\end{array}$ & $\begin{array}{l}+ \\
-\end{array}$ & $\begin{array}{l}\text { Blood } \\
\text { Lab. isolate, normal }\end{array}$ \\
\hline E. coli & $\begin{array}{l}\text { M3 } \\
T Z\end{array}$ & $\begin{array}{l}+ \\
-\end{array}$ & - & $\begin{array}{c}+ \\
\text { ND }\end{array}$ & $\begin{array}{l}+ \\
-\end{array}$ & $\begin{array}{l}+ \\
-\end{array}$ & $\begin{array}{c}+ \\
\text { ND }\end{array}$ & $\begin{array}{l}\text { Colon cancer tissue } \\
\text { Urine, pregnancy }\end{array}$ \\
\hline $\begin{array}{l}\text { Corynebacterium } \\
\text { (diphtheroid) }\end{array}$ & $\begin{array}{l}\text { JB-I }(9 / 12 / 79 \\
\text { to } 2 / 81) \\
J B-I I(10 / 81)\end{array}$ & $\begin{array}{l}+ \\
-\end{array}$ & $\begin{array}{c}+ \\
\text { ND }\end{array}$ & $\begin{array}{l}\text { ND } \\
\text { ND }\end{array}$ & $\begin{array}{l}+ \\
-\end{array}$ & $\begin{array}{l}+ \\
-\end{array}$ & $\begin{array}{l}\text { ND } \\
\text { ND }\end{array}$ & $\begin{array}{l}\text { Urine, pregnancy } \\
\text { Urine, pregnancy }\end{array}$ \\
\hline
\end{tabular}

* Strains used as negative controls are shown in italic type.

$\dagger$ Whole, antiserum to whole hCG; MoAb, monoclonal antibody to hCG $\beta ; \beta$, antiserum to hCG $\beta, \beta \mathrm{COOH}$, antiserum to carboxy-terminal peptide of $\mathrm{hCG} \beta ; \alpha$, antiserum to $\mathrm{hCG} \alpha$. + , positive reaction; - , negative reaction; VE, variable expression; ND, not done.

$\ddagger$ Identification verified by DNA-DNA hybridization.

We also used two monoclonal antibodies (MoAbs) against hCG $\beta$; one (CS-3F8) was a culture supernate supplied by Kevin Gilbride (formerly from Cappel Laboratories), and the other (337W) was a purified IgG $_{1}$ from ascites fluid, given to us by David Beckman (Chemicon International Inc., El Segundo, Calif., USA). Both MoAbs reacted with hCG $\beta$ and with whole hCG; they were directed against different epitopes of hCG $\beta$. All these reagents were used as first antibodies.

The second antibodies, viz. fluorescein-labelled goat antirabbit IgG, peroxidase-labelled goat antirabbit IgG, and peroxidase-labelled sheep antimouse IgG, were commercially obtained from Cappel Laboratories as were the reagent controls for the immunocytochemical reactions (a rabbit antiserum to chicken haemoglobin, nonimmunized rabbit and goat sera, culture supernate control NS-2, cat. no. 0101-2407, and ascites control NS-1, cat. no. 0201-337). Peroxidase staining was done with 3,3'-diaminobenzidine tetrahydrochloride in the earlier years and with 3-amino-9-ethylcarbazole (Sigma) from 1981.

Electron microscopy. For TEM studies, all bacteria (hCG-producers and controls) were grown aerobically in Trypticase soy broth at $35^{\circ} \mathrm{C}$ for $18 \mathrm{~h}$ and subsequently fixed for a minimum of $2 \mathrm{~h}$ with cold $\left(4{ }^{\circ} \mathrm{C}\right) 3 \%(\mathrm{w} / \mathrm{v})$ glutaraldehyde in $0.1 \mathrm{M}$-phosphate buffer $\mathrm{pH} 7.4$ containing $1 \%(\mathrm{w} / \mathrm{v}) \mathrm{CaCl}_{2}$. Subsequent preparation of the specimens was as described by Acevedo et al. $(1981 \mathrm{~b})$.

\section{RESULTS}

\section{Identification of micro-organisms}

By using the procedures described in Methods, the bacterial strains were identified as: Staphylococcus haemolyticus, two strains; Streptococcus faecalis, three strains; and single strains of Staphylococcus epidermidis, Streptococcus bovis, Escherichia coli and an aerobic Corynebacterium (Table 1). Of the five strains of 'Progenitor cryptocides' obtained from Dr LivingstonWheeler, two, PC-RU1 and PC-M, were identified as Staph. haemolyticus (Acevedo et al., 1985). Their identification was further verified by DNA-DNA hybridization techniques. Strain PC-A was identified as Staph epidermidis (Acevedo et al., 1985), and the other two, PC-C and PC-E, were identified as Strep. faecalis. Strain AV-46 was identified as Strep. bovis.

Strain JB-I was isolated in August 1979 from the urine of a pregnant woman. During the first two weeks of its isolation, Gram staining demonstrated a Gram-negative coccus. Two weeks later, after several passages, it had changed to a Gram-negative diphtheroid with a 

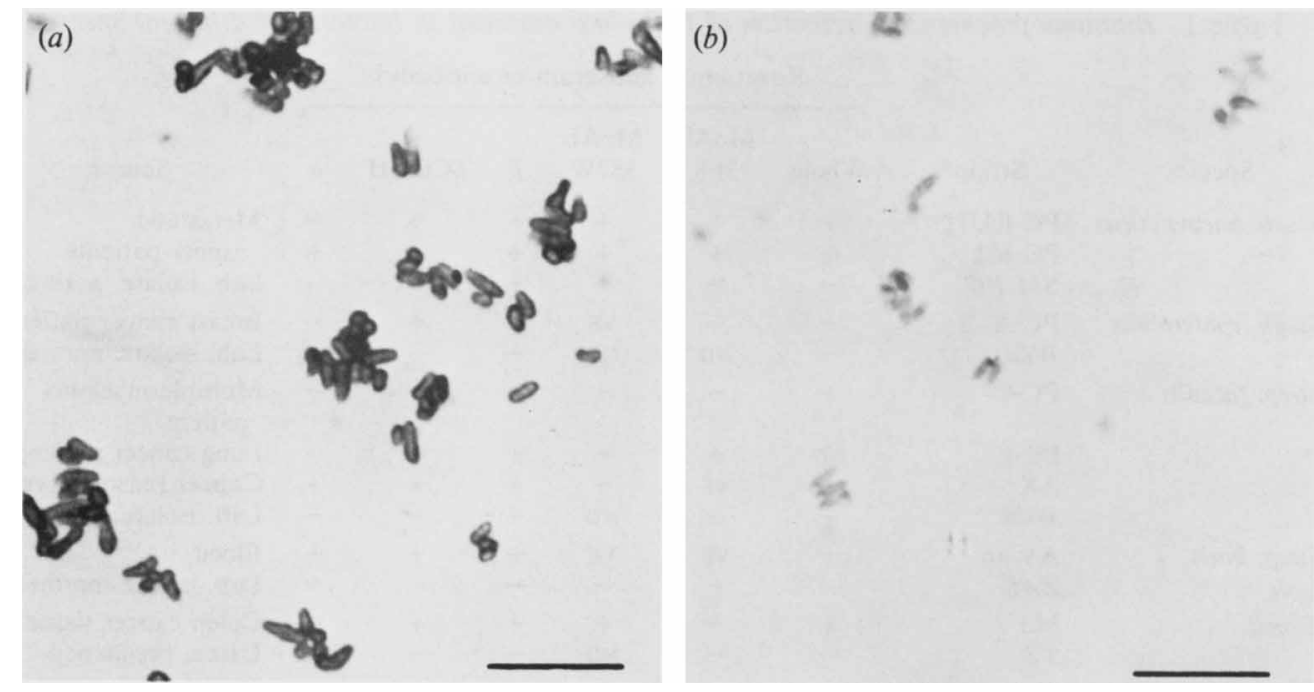

Fig. 1. (a) Immunocytochemical detection of hCG-like material in the Gram-negative diphtheroid Cornyebacterium JB-I. Indirect immunoperoxidase reaction using rabbit antiserum (R-112) against hCG $\alpha$ as first antibody; unfixed, air-dried cells. Note the characteristic 'picket fence' arrangement of cells. (b) Reagent control of the indirect immunoperoxidase reaction in Corynebacterium JB-I, demonstrating a negative reaction The first antibody was replaced by rabbit antiserum to chicken haemoglobin. Bars, $10 \mu \mathrm{m}$.

characteristic 'picket fence' arrangement of cells. It remained as such until December 1980, when it became a Gram-variable diphtheroid. It continued as such until in October 1981 it stained as a Gram-positive diphtheroid with a positive Loeffler test typical of an aerobic Corynebacterium. It was called Corynebacterium strain JB-II and was finally identified as a ' $C$. ulcerans' strain. The Gram-negative diphtheroid was named Corynebacterium strain JB-I.

\section{Immunocytochemistry}

The nine strains from the six species expressed immunoreactive hCG-like material on their cell surface, while all the control bacteria were negative for all the reagents used (Table 1). Three of the eight bacterial strains tested with antiserum to $\mathrm{hCG} \alpha$, Staph. epidermidis PC-A, and Strep. faecalis PC-C and PC-E, did not react.

The results of the reactions done with MoAb 3F8 demonstrated that this particular hCG $\beta$ epitope was expressed consistently in four of the nine strains, while there was variable expression of the epitope in two strains (Strep. faecalis AK and Strep. bovis AV-46) and it was not expressed or not available to the antibody in three strains (Staph. epidermidis PC-A, Strep. faecalis $\mathrm{PC}-\mathrm{C}$ and $E$. coli $\mathrm{M} 3$ ). On the other hand, the reactions done with MoAb $337 \mathrm{~W}$ showed that the epitope was expressed in five of the eight strains that were tested, that there was a variable expression of the epitope in two strains (Staph. epidermidis PC-A and Strep. bovis AV46) and that it was not available or not expressed in one (Strep. faecalis PC-E).

The results of the immunocytochemical studies on Corynebacterium JB-I demonstrated expression of hCG-like material with all the reagents used (Table 1, Fig. 1) while the bacteria were Gram-negative or slightly Gram-variable (Corynebacterium JB-I). Reactions were negative when the bacteria became Gram-positive diphtheroids (Corynebacterium JB-II, 'C. ulcerans').

\section{Electron microscopy}

The TEM studies revealed atypical morphology in six of the nine strains, Staph. haemolyticus RU1 and PC-M, Staph. epidermidis PC-A, Strep. bovis AV-46, E. coli M3 and Corynebacterium JB-I. The atypical morphology varied from cytoplasmic alterations and ultrastructural changes in the cell walls as illustrated by E. coli M3 (Fig. 2a), Staph. epidermidis PC-A (Fig. 3), and Strep. bovis AV-46 (Fig. 4), to bizarre forms of cell division with loss of binary fission as illustrated by 


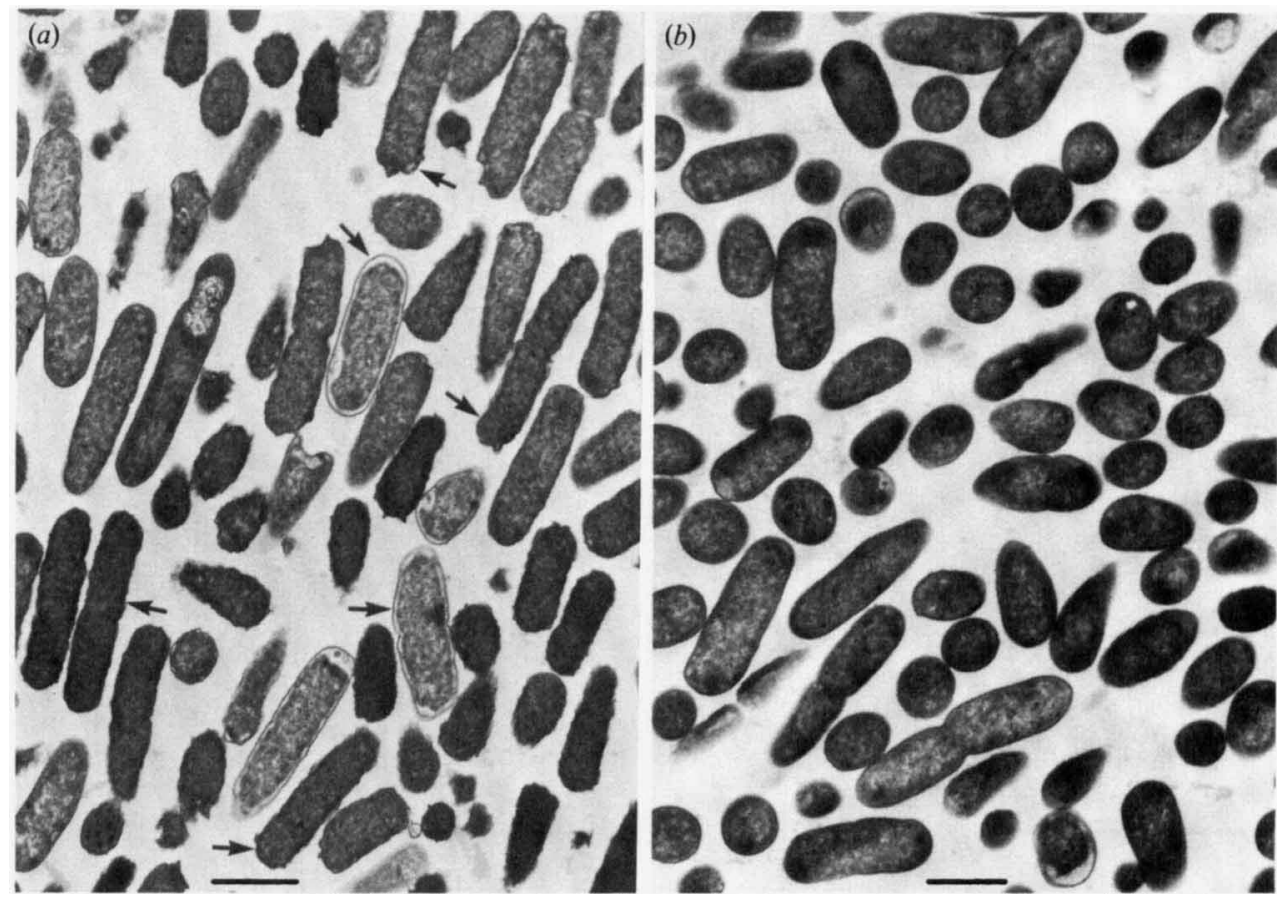

Fig. 2. (a) Low magnification of a thin section of $E$. coli M3 demonstrating an altered cytoplasm and cell wall (cf. $b$ ). Note the rough appearance of a thin cell wall in several cells in contrast to the thicker walls demonstrated in others (arrows), and the variable density of the cytoplasm. (b) Low magnification of a thin section of $E$. coli TZ, hCG-negative control for comparison with $E$. coli M3. Bars, $1 \mu \mathrm{m}$.

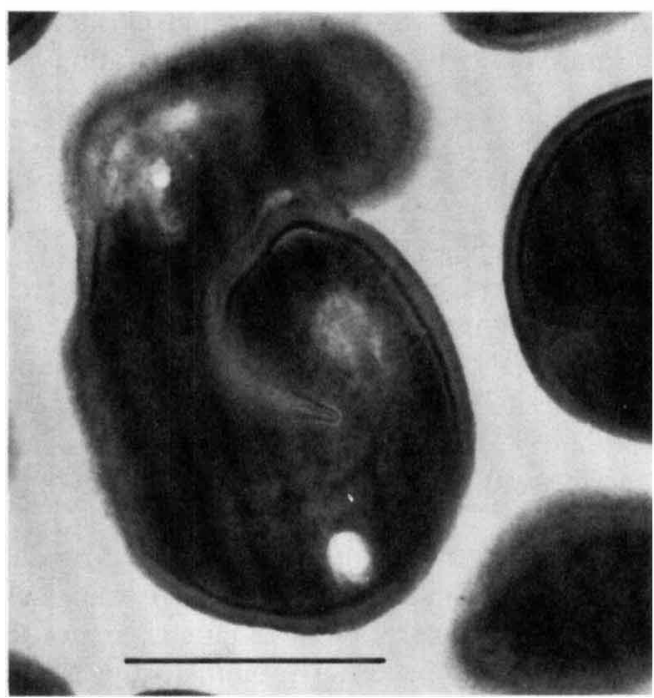

Fig. 3

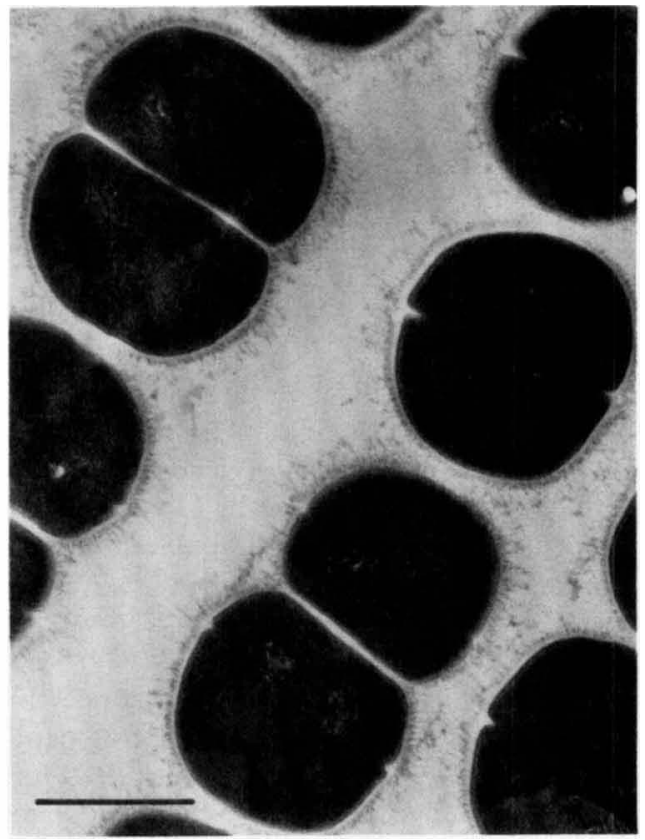

Fig. 4

Fig. 3. High magnification of a thin section of Staph. epidermidis PC-A showing extreme pleomorphism. Bar, $0.5 \mu \mathrm{m}$.

Fig. 4. High magnification of a thin section of the revertant Strep. bovis AV-46 showing a thin cell wall covered with fibrillar material. Bar, $0.5 \mu \mathrm{m}$. 


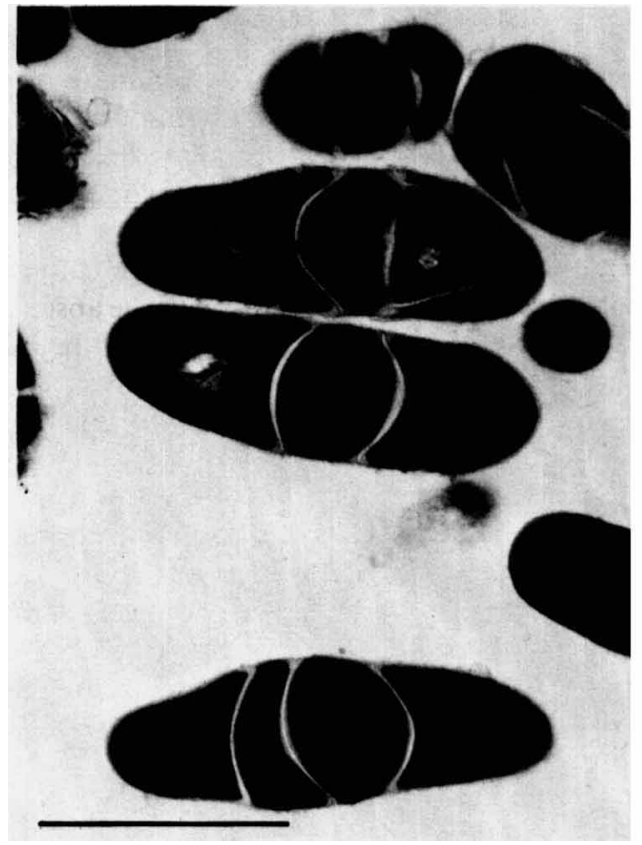

Fig. 5

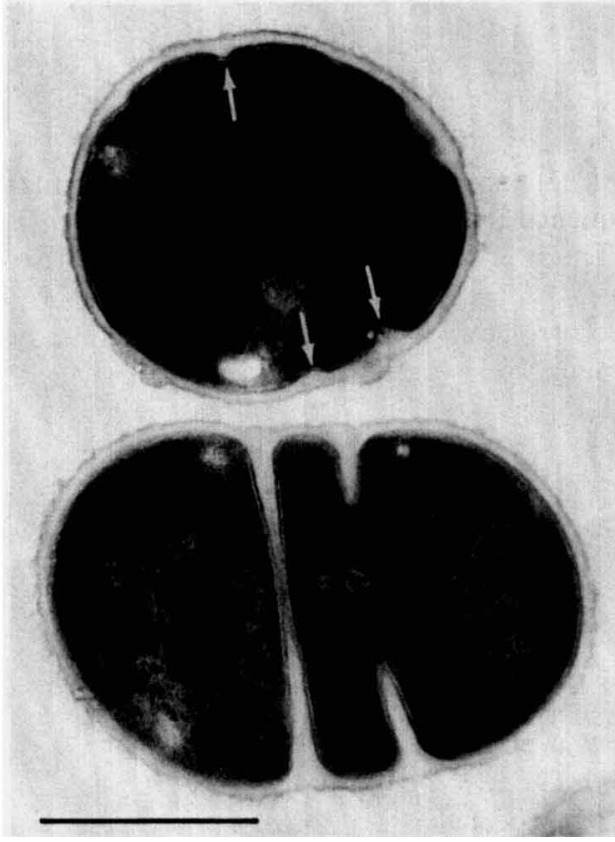

Fig. 6

Fig. 5. High magnification of a thin section of Corynebacterium JB-I, showing bizarre forms with distorted septa. Bar, $1 \mu \mathrm{m}$.

Fig. 6. High magnification of a thin section of Staph. haemolyticus PC-M, showing multiple septation without cell separation. What appears to be the beginning of some grooves can be noted in the upper cell (arrows). Bar, $0.5 \mu \mathrm{m}$.

Corynebacterium JB-I (Fig. 5) and Staph. haemolyticus PC-M (Fig. 6). Because of all these characteristics, pleomorphism among some of these bacteria was notable. Control bacteria, grown and processed in identical conditions, did not show any morphological alterations, as illustrated by the control E. coli TZ (Fig. $2 b$ ).

\section{DISCUSSION}

The results of this investigation, in which modern identification methods were used, proved that the hCG-producing bacteria isolated from patients with overt cancer do not constitute a new species, 'Progenitor cryptocides', as claimed by Livingston \& Livingston (1974). We extended the studies done by Domingue (1982), where DNA-DNA hybridization techniques were used to demonstrate that several of the strains identified as 'P. cryptocides' were not related to each other. Our recent studies (Acevedo et al., 1985), using the same techniques, also demonstrated that several strains reported as 'P. cryptocides' were in fact different species of the genus Staphylococcus.

The immunocytochemical tests done with antisera against the whole hormone, its individual subunits and the carboxy-terminal fragment of the $\beta$-subunit, and with the MoAbs reacting with two different hCG $\beta$ epitopes, permitted immunochemical recognition of different parts of the hCG-like molecule and showed a close resemblance of the bacterial protein to the human trophoblastic hormone.

When preparing polyclonal antiserum or MoAbs against hCG or its fragments, it is important to note that when the complete hormone is used as immunogen, the antiserum obtained crossreacts with both the $\alpha$-and $\beta$-subunits and also with the hypophyseal hormone lutropin (human 
luteinizing hormone), but it does not react with the carboxy-terminal peptide of its $\beta$-subunit, the 30 -amino-acid segment which is unique to hCG. In the same way, when hCG $\beta$ is used as immunogen it seldom, if ever, gives rise to antibodies reacting with its carboxy-terminal region (Birken et al., 1982). Therefore the reactivity with antiserum to the carboxy-terminal peptide that was shown by all nine strains tested (Table 1) indicated that these bacteria were expressing a molecule or part of a molecule rather similar to the complete hCG, since the 30 amino acid sequence by itself is not the product of a de novo natural synthesis.

The specificity of the antisera to hCG $\beta$ that we have used has been well established, not only by all the usual controls for immunocytochemistry, but also by our demonstration of the absence of cross-reactivity between the antisera and cholera toxin (Acevedo et al., 1980), and by our demonstration of the lack of immunological analogy between the $\beta$-subunits of cholera toxin and hCG $\beta$ in spite of their structural relatedness, the common CAGY segment (Acevedo \& Kellen, 1985).

A positive reaction with the hCG $\beta$ MoAbs indicated the presence of a given hCG $\beta$ antigenic determinant. In conjunction with the results obtained with the polyclonal antisera, the positive reactions gave strong evidence for molecular similarity of the bacterial product and the human trophoblastic hormone. A negative reaction does not negate the presence of the hCG-like material, since the lack of reactivity could be due to the low sensitivity characteristic of MoAbs, or to the particular epitope being either masked or not expressed. In this respect, our results (Table 1), demonstrated that both epitopes of hCG $\beta$ were available in Staph. haemolyticus PCRU1 since the reactions done with each MoAb were positive. On the other hand, Strep. faecalis $\mathrm{PC}-\mathrm{C}$ reacted with MoAb 337W but not with MoAb 3F8, demonstrating that in this strain there was a variation in the availability or expression of these particular epitopes. This variable expression was demonstrated further by Staph. epidermidis PC-A, which gave a negative reaction with MoAb 3F8, while some cells reacted positively and others negatively with MoAB $337 \mathrm{~W}$, showing that in this strain there was also a clonal variation in the expression of this particular hCG $\beta$ epitope. Moreover, our studies of the expression of hCG-like material in coagulase-negative staphylococci have demonstrated the existence, not only of a clonal variation in the availability or expression of a single epitope, but also of a clonal variation in the expression of the whole antigen and/or its subunits and fragments in 19 strains belonging to seven of the eight species of Staphylococcus that were investigated (Acevedo et al., 1985). The mechanism of this variable phenotypic expression of the hCG-like material by these bacteria is unknown. The phenomenon may be controlled by a labile plasmid, by a transposable element or by DNA inversions, since genetic switches by DNA inversions in prokaryotes have been postulated for Enterobacteriaceae (Plasterk \& van de Putte, 1984).

The similarity of the bacterial factor to the human trophoblastic hormone was further supported by the results showing that three of the eight strains tested with antiserum to $\mathrm{hCG} \alpha$, Staph. epidermidis PC-A, and Strep. faecalis PC-C and PC-E, did not express the $\alpha$-subunit. This lack of expression of material similar to $\mathrm{hCG} \alpha$ has also been observed in different species of coagulase-negative Staphylococcus (Acevedo et al., 1985). This can occur because independent synthesis of hCG subunits by malignant cells and by placental trophoblasts is a common event, their synthesis being controlled by different genes (Hussa, 1980; Boothby et al., 1981; Boorstein et al., 1982). These biological similarities have been extended further by our findings that vaccines prepared with phenol-or formalin-killed hCG-producing bacteria induce in rabbits the production of antibodies which cross-react with hCG (Domingue et al., 1986).

The morphological alterations observed in S. bovis AV-46 (Fig. 4) and Corynebacterium JB-I (Fig. 5) were not surprising since they have been described previously as primary characteristics of CWD variants and filterable, cryptic bacteria isolated from blood lysates of diseased humans (Domingue \& Schlegel, 1977; Domingue, 1982; Heidger et al., 1982). No alterations were demonstrated by their respective controls. Similarly, the morphological changes demonstrated in Staph. haemolyticus RUI and PC-M, Staph. epidermidis PC-A (Fig. 3) and E. coli M3 (Fig. 2a), were not shown in their corresponding controls, grown and processed under identical conditions, as illustrated by $E$. coli TZ (Fig. $2 b$ ). It is important to note that this non-producer control bacterium was isolated from the urine of a pregnant woman, containing therefore high 
amounts of hCG, thus suggesting that the observed alterations of the hCG-producers were not due to the trophoblastic hormone, since this control bacterium was growing naturally in the presence of a high concentration of hCG.

The morphological alterations demonstrated by these bacteria suggested that some hCGproducing bacteria may undergo a CWD phase. Changes in cell wall anatomy may explain the altered Gram reaction demonstrated by Corynebacterium JB-I. It is also possible that the alterations occurring at the level of the cell wall during reversion may produce changes in the antigenic characteristics of these bacteria, leading to altered immunological responses in the host. It is now known that there are immunological specificities associated with certain CWD bacteria that are not evident when intact parental organisms are utilized as immunogens. These have been well documented with CWD variants of group A streptococci (Lynn, 1982). Because of these characteristics, hCG-producing bacteria as CWD variants or revertants may have pathophysiological importance especially if an association exists between these bacteria and the process of malignant transformation, since most of these bacteria have been isolated from patients with clinically manifested cancer (Cohen \& Strampp, 1976; Acevedo et al., 1978, 1985; Backus \& Affronti, 1981).

In conclusion, our investigations have: (1) demonstrated beyond doubt that bacteria expressing hCG-like material isolated from patients with overt cancer are not a new and unique species as claimed by others; (2) shown that there is very close resemblance between the bacterial protein and the human trophoblastic hormone, both on the basis of immunochemical recognition of different parts of the hCG-like molecule, and in its biological behaviour; and (3) suggested that morphological changes, as observed by electron microscopy, may indicate that at least some of the bacteria expressing the hCG-like material may be revertants of CWD variants, a condition with possible pathophysiological significance.

This work was supported by a donation in memory of Brooke D. Cadwallader, and by grants from the Cancer Research Foundation of Pittsburgh, the Cancer Federation, Inc., and the Allegheny-Singer Research Institute.

\section{REFERENCES}

Acevedo, H. F. \& Kellen, J. A. (1985). Lack of immunological analogy between the $\beta$-subunits of cholera toxin and human choriogonadotropin. Tumour Biology 6, 447-452.

ACEvedo, H. F., Slifkin, M., Pouchet, G. R. \& PARDO, M. (1978). Immunohistochemical localization of a choriogonadotropin-like protein in bacteria isolated from cancer patients. Cancer 41, 1217-1219.

ACEvedo, H. F., Slifkin, M., Pouchet-Melvin, G. R. \& CAMPBell-ACEvedo, E. A. (1979). Choriogonadotropin-like antigen in an anaerobic bacterium, Eubacterium lentum, isolated from a rectal tumor. Infection and Immunity 24, 920-924.

ACEvedo, H. F., Campbell-ACEvedo, E. A. \& SLIFKIN, M. (1980). Immunodetection of choriogonadotropin-like antigen in bacteria isolated from cancer patients. In Chorionic Gonadotropin, pp. 435460. Edited by S. J. Segal. New York: Plenum.

Acevedo, H. F., Kolde, S. S., Slifkin, M., Maruo, T. \&CAMPBELL-ACEVEDO, E.A.(1981 $a$ ). Choriogonadotropin-like antigen in a strain of Streptococcus faecalis and a strain of Staphylococcus simulans. Detection, identification and characterization. Infection and Immunity 31, 487-494.

Acevedo, H. F., Campbell-Acevedo, E. A., Pardo, M. \& SLIFKIN, M. $(1981 b)$. Immunohistochemical localization of choriogonadotropin-like antigen in animal malignant cells. In Tumor Imaging. The
Radioimmunochemical Detection of Cancer, pp. 73-88. Edited by S. B. Burchiel, B. A. Rhodes \& B. Friedman. New York, NY: Masson Publishing USA.

Acevedo, H. F., Campbell-Acevedo, E. A. \& Kloos, W. E. (1985). Expression of choriogonadotropin-like material in coagulase-negative Staphylococcus species. Infection and Immunity 50, 860-868.

BaCKUS, B. T. \& AfFronTI, L. F. (1981). Tumor associated bacteria capable of producing a human choriogonadotropin-like substance. Infection and Immunity 32, 1211-1215.

Birken, S. \& CANFIELD, R. E. (1980). Chemistry and immunochemistry of human chorionic gonadotropin. In Chorionic Gonadotropin, pp. 65-88. Edited by $S$. J. Segal. New York: Plenum.

Birken, S., Canfield, R., Agosto, G. \& Lewis, J. (1982). Preparation and characterization of an improved $\beta$-COOH-terminal immunogen for generation of specific and sensitive antisera to human chorionic gonadotropin. Endocrinology 110, 15551563.

Boorstein, W. R., Vamvakopoulos, N. C. \& Fiddes, J. C. (1982). Human chorionic gonadotropin $\beta$ subunit is encoded by at least eight genes arranged in tandem and inverted pairs. Nature, London 300, 419422.

BOOthby, M., RUdDin, R. W., ANdERSON, C., McWilliams, C. \& Boime, I. (1981). A single 
gonadotropin $\alpha$-subunit gene in normal tissue and tumor-derived cell lines. Journal of Biological Chemistry 256, 5121-5127.

BRENNER, D. J., FANNING, G. R., RAKe, A. \& JoHnson, K. E. (1969). A batch procedure for thermal elution of DNA from hydroxyapatite. Analytical Biochemistry 28, 447-459.

CoHen, H. \& STRAMPP, A. (1976). Bacterial synthesis of substances similar to human chorionic gonadotropin. Proceedings of the Society for Experimental Biology and Medicine 152, 408-410.

Domingue, G. J. (1982). Filterable, cell-associated cell wall-deficient bacteria in renal diseases. In Cell Wall-deficient Bacteria, Basic Principles and Clinical Significance, pp. 121-148. Edited by G. J. Domingue. Reading, MA: Addison-Wesley.

Domingue, G. J. \& Schlegel, J. U. (1977). Novel bacterial structures in human blood. Cultural isolation. Infection and Immunity 15, 621-627.

Domingue, G. J., Acevedo, H. F., Powell, J. E. \& Stevens, V. C. (1986). Antibodies to bacterial vaccines demonstrating specificity for human choriogonadotropin (hCG) and immunochemical detection of hCG-like factor in subcellular bacterial fractions. Infection and Immunity 53, 95-98.

Heidger, P. M., JR, Domingue, G. J., Larsen, W. J. \& SMITH, T. W., JR. (1982). Fine structural studies of cell wall-deficient bacteria isolated from blood and urine. In Cell Wall-deficient Bacteria, Basic Principles and Clinical Significance, pp. 149-185. Edited by G. J. Domingue. Reading, MA: Addison-Wesley.

HussA, R. O. (1980). Biosynthesis of human chorionic gonadotropin. Endocrine Reviews 1, 268-294.
Kloos, W. E. \& Schleifer, K. H. (1975). Simplified scheme for routine identification of human Staphylococcus species. Journal of Clinical Microbiology 1, 8288 .

KLOOS, W. E. \& WolfSHOHL, J. F. (1979). Evidence for deoxyribonucleotide sequence divergence between staphylococci living on human and other primate skin. Current Microbiology 3, 167-172.

Kloos, W. E. \& Wolfshohl, J. F. (1982). Identification of Staphylococcus species with the API STAPHIDENT system. Journal of Clinical Microbiology 16, 509-516.

Livingston, V. W. C. \& AleXander-Jackson, E. (1970). A specific type of organism cultivated from malignancy. Annals of the New York Academy of Sciences 174, 636-654.

Livingston, V. W. C. \& Livingston, A. M. (1974). Some cultural, immunological and biochemical properties of Progenitor cryptocides. Transactions of the New York Academy of Sciences 36, 569-582.

LYNN, R. J. (1982). Serologic and immunologic characteristics of cell wall-deficient bacteria: Antigenic structure. In Cell Wall-deficient Bacteria, Basic Principles and Clinical Significance, pp. 59-74. Edited by G. J. Domingue. Reading, MA: Addison-Wesley. Maruo, T., Cohen, H., Segal, S. J. \& Koide, S. S. (1979). Production of choriogonadotropin-like factor by a microorganism. Proceedings of the National Academy of Sciences of the United States of America 76, 6622-6626.

Plasterk, R. H. A. \& VAN de Putte, P. (1984). Genetic switching by DNA inversions in prokaryotes. Biochimica et biophysica acta 782, 111-119. 